\title{
ORGANIZAČNÉ OBČIANSKE SPRÁVANIE, ORGANIZAČNÁ SPRAVODLIVOSŤ A SOCIO-DEMOGRAFICKÉ UKAZOVATELE
}

\author{
Denisa Rovenská
}

\begin{abstract}
Abstrakt
Kvalitu a efektivitu organizácie určuje nielen manažment, organizačná štruktúra či kultúra, ale aj jej zamestnanci a aktivity, ktoré determinujú ich vzt’ah $\mathrm{k}$ danej organizácii. Správanie zamestnancov nezahŕňa len formálne určené aktivity, ale najmä aktivity, ktoré sú na báze dobrovol'nosti. Daná dobrovol'nost' sa prejavuje predovšetkým v rámci organizačného občianskeho správania (z angl. organizational citizenship behavior, d'alej len OCB). Mieru OCB určujú viaceré organizačné faktory, medzi ktoré patrí aj organizačná spravodlivost'. Ciel'om predkladaného príspevku bolo objasnit' charakter vzt'ahu medzi organizačným občianskym správaním, organizačnou spravodlivost'ou a vybranými socio-demografickými ukazovatel'mi. Zámer sa tiež sústredil na poznanie miery organizačného občianskeho správania, ktoré respondenti vykazujú a tiež, v akej miere vnímajú jednotlivé dimenzie organizačnej spravodlivosti. Pre naplnenie spomenutého ciel'a sa 210 respondentov s priemerným vekom 34,82 rokov $(\mathrm{SD}=10,97)$ vyjadrilo $\mathrm{k}$ otázkam, ktoré zaznamenávali mieru organizačného občianskeho správania pomocou dotazníka Organizational Citizenship Behavior Checklist (OCB-C) a mieru organizačnej spravodlivosti prostredníctvom škály Organizational Justice Scale. Výsledky ukázali, že v priemere respondenti vykazovali nižšiu mieru OCB $(\mathrm{M}=2,28$; $\mathrm{SD}=0,67)$ a v rámci organizačnej spravodlivosti $\mathrm{v}$ najvyššej miere vnímali interpersonálnu spravodlivost' $(\mathrm{M}=3,78 ; \mathrm{SD}=1,05)$. Analýza charakteru vzt'ahov medzi vybranými premennými ukázala, že dimenzie organizačnej spravodlivosti, odpracované roky v organizácii a rod boli prediktormi OCB, resp. OCB-O a OCB-I. Konkrétne výsledky sú súčast'ou príspevku.
\end{abstract}

Kl’účové slová: organizačné občianske správanie, organizačná spravodlivost', sociodemografické ukazovatele, lineárny model

\section{ORGANIZATIONAL CITIZENSHIP BEHAVIOR, ORGANIZATIONAL JUSTICE AND SOCIO-DEMOGRAPHIC VARIABLES}

\begin{abstract}
The quality and efficiency of an organization are determined not even by the management, organizational structure or the company culture, but also employees and their behavior which determine the relationship to the organization. Employees' behavior does not only include formally defined activities, but especially activities that are voluntary. These activities are manifested primarily in an organizational citizenship behavior (OCB).
\end{abstract}


The OCB is determined by a number of organizational factors, including organizational justice. The aim of this contribution was to analyze the relationship between organizational citizenship behavior, organizational justice and selected socio-demographic variables. The research also focused on the frequency of $O C B$ and the level of organizational justice perception. 210 respondents in total with the average age of 34.82 years $(S D=10.97)$ answered the questions measuring $O C B$ by Organizational Citizenship Behavior Checklist $(O C B-C)$ and organizational justice by Organizational Justice Scale. The results showed that respondents had a lower level of $O C B \quad(M=2.28 ; S D=.67)$, and they perceive interpersonal justice the most $(M=3.78 ; S D=1.05)$ within organizational justice. An analysis of the nature of the relation between selected variables showed that dimensions of organizational justice, years of practice and gender were predictors of $O C B, O C B-O$ or/and $O C B-I$, respectively. Specific results are part of the contribution.

Keywords: organizational citizenship behavior, organizational justice, socio-demographic variables, linear model

Došlo: 17. 5. 2019

Schváleno: 23. 10. 2019

\section{Teoretické východiská}

Práca má pre človeka významné postavenie $\mathrm{v}$ jeho živote, pretože mu dáva pocit zadost'učinenia, zmysluplnosti, je cestou i ciel'om. Pracovné prostredie má na jedinca významný vplyv, nakol'ko je dôležitým faktorom motivácie, výkonnosti alebo spokojnosti samotného zamestnanca. Ak je pracovné prostredie kvalitné, či už na úrovni materiálnych, organizačných alebo sociálnych podmienok, aktivita zamestnanca nie je v zhode len s formálnymi náležitost’ami organizácie, ale odráža sa aj v rovine nepísaných (neformálnych) činností.

Jednou z takýchto nepísaných, resp. neformálnych aktivít je napríklad organizačné občianske správanie ( $\mathrm{z}$ angl. organizational citizenship behavior; d'alej len OCB). Koncept OCB je v pozornosti odborníkov už niekol'ko dekád, jedným z prvých príspevkov venovaných danej problematike bol článok od Smithovej, Organa a Nearovej (1983), ktorí sa snažili popísat' charakter a dimenzie OCB. Neskôr ponúkol Organ (1988) definíciu OCB, ktoré charakterizoval ako individuálne správanie, ktoré je dobrovol'né, nie je priamo alebo explicitne priznané formálnym odmeňovacím systémom a celkovo podporuje efektívne fungovanie organizácie. 
Táto definícia zahŕňa ako aspekt behaviorálny, tak aj aspekt dôsledkov a zdôrazňuje, že tento druh aktivít je (1) dobrovol'ný, a teda nie je súčast'ou formálnych pracovných požiadaviek, (2) nie je priamo spojený s formálnym odmeňovaním a (3) je benefitom pre efektívnost' organizácie. Samozrejme, táto definícia si vyslúžila viaceré kritické pohl'ady, ktoré vyčítali najmä fakt, že zamestnanci môžu vnímat' elementy OCB viac menej ako súčast' ich práce a netvoria jasnú hranicu medzi dobrovol'ným správaním a pracovnými požiadavkami. Ďalšou kritikou bolo, že niektoré odmeny nie sú zmluvne garantované formálnym odmeňovacím systémom (napr. povýšenie) a môžu byt' výsledkom, benefitom zaangažovania sa do aktivít OCB (Organ, 1997). Prirodzene, Organ (1997, p. 95) na túto spätnú väzbu reagoval a následne upravil definíciu v podobe „OCB je správanie, ktoré prispieva k organizačnej efektívnosti cez podporu sociálneho a psychologického prostredia, kde dochádza k plneniu pracovných úloh“.

Podl'a Organa (1988) zamestnanci, ktorí prejavujú OCB sú tí, ktorí sú ochotní prijímat' d’alšie úlohy, ktoré môžu, ale nemusia súvisiet' s ich pracovnými povinnost'ami, ako je napríklad udržiavanie čistého a uprataného pracovného prostredia, riešenie pracovných problémov svojich kolegov, poskytovanie osobnej pomoci kolegom, ktorí sú v núdzi alebo práca mimo bežného pracovného času (bez toho, aby sa st’ažovali).

Pôvodne bolo OCB chápané v rovine 2 dimenzií, a to (1) altruizmu (z angl. altruism) a všeobecnej poslušnosti (z angl. generalized compliance) (Smith, Organ, \& Near, 1983). Altruizmus v tomto prípade reprezentoval pomoc poskytnutú konkrétnym jedincom, zatial' čo všeobecná poslušnost' bol faktor definovaný cez menej osobný druh mravnosti, kde je potrebné robit' veci správne a dôsledne, ale skôr v záujme systému a nie vo vzt'ahu ku konkrétnej osobe (Smith, Organ, \& Near, 1983). Organ (1988) prepracoval koncept všeobecnej poslušnosti a rozšíril taxonómiu OCB o d'alšie dimenzie, konkrétne (1) altruizmus (z angl. altruism), (2) svedomitost' ( $z$ angl. conscientiousness), (3) zdvorilost' ( $z$ angl. courtesy), (4) športové správanie ( $\mathrm{z}$ angl. sportsmanship) a (5) občianska cnost' ( $\mathrm{z}$ angl. civic virtue).

Taxonómia OCB bola viackrát dopíňaná a ako uvádzajú Podsakoff et al. (2000), v literatúre je možné nájst' viac ako 30 rôznych dimenzií OCB, pričom mnohé konštrukty sa vo svojej podstate prekrývajú. Na základe analýz jednotlivých taxonómií tak autori navrhli 7 spoločných dimenzií (Podsakoff et al., 2000):

1. pomáhajúce správanie ( $\mathrm{z}$ angl. helping behavior) - zahŕňa dobrovol'né pomáhanie iným alebo preventívne správanie namierené proti výskytu problémov súvisiacich s prácou;

2. športové správanie ( $\mathrm{z}$ angl. sportsmanship) - druh správania, ktorý zamestnanci prejavujú tak, že sa nest’ažujú, ked' sú obt’ažovaní inými, udržiavajú pozitívny postoj, ked' sa im nedaria veci, nie sú urazení, ak ostatní nesúhlasia s ich názormi, sú ochotní obetovat' vlastné záujmy pre dobro pracovnej skupiny a neberú osobne odmietnutie ich nápadov;

3. lojalita voči organizácii (z angl. organizational loyalty) - spočíva v prezentovaní organizácie navonok, ochrane organizácie pred vonkajšou hrozbou a zachovávaní zaviazanosti aj v prípade nepriaznivých podmienok;

4. poslušnost' voči organizácii (z angl. organizational compliance) - súvisí s internalizáciou a prijatím pravidiel, nariadení a postupov organizácie, čoho výsledkom je ich dôsledné dodržiavanie; 
5. individuálna iniciatíva ( $\mathrm{z}$ angl. individual initiative) - tento druh správania zahŕňa dobrovol'né aktivity spojené s kreativitou a inováciami zameranými na rozvoj, zlepšovanie úloh, výkonnosti, prejavujúca sa vysokou mierou entuziazmu, úsilím splnit' úlohy, ochotou dobrovol'ne prevziat' povinnosti naviac a povzbudzovaním ostatných $\mathrm{v}$ organizácii, aby konali rovnako;

6. občianska cnost' ( $\mathrm{z}$ angl. civic virtue) - predstavuje záväzok voči organizácii ako celku, je prejavom ochoty aktívne participovat' na jej riadení (zasadnutia, vyjadrenie názoru), pozorovat' jej prostredie pre prípadné hrozby alebo príležitosti (citlivost' na zmeny, sledovanie trendov) a byt' pripravený na zlepšovanie jej záujmov (osobný vklad);

7. sebarozvoj (z angl. self development) - spočíva v dobrovol'ných aktivitách, ktoré rozvíjajú vedomosti, zručnosti a schopnosti jednotlivých zamestnancov.

Na strane druhej, Williams a Andersonová (1991) tvrdia, že OCB by malo byt' kategorizované skôr na základe orientácie, smerovania jednotlivých aktivít, a nie na základe ich obsahu. Konkrétne majú autori na mysli usporiadanie OCB v rámci dvoch smerov, a to (1) na správanie, ktoré je zamerané na jednotlivca/kolegu, t.j. interpersonálna rovina (d’alej len OCB-I; v niektorých odborných zdrojoch je možné nájst' označenie OCB-P) a (2) na správanie, ktoré smeruje k organizácii, t.j. organizačná rovina (d’alej len OCB-O). OCB-O je typom správania, ktoré prináša prospech organizácii vo všeobecnosti a udržiava organizačné pravidlá a politiku. Naopak, OCB-I je typom správania, ktoré prináša prospech konkrétnym jednotlivcom a nepriamo prispieva $\mathrm{k}$ efektívnosti organizácie (Williams \& Anderson, 1991). S touto kategorizáciou sa stotožňujú aj iní autori (pozri napr. Ilies et al., 2009; McNeely \& Meglino, 1994). Tento model predpokladá, že správanie odrážajúce altruizmus, pomoc či zdvorilost' je namierené k l'ud'om, zatial' čo aktivity ako občianska cnost', športové správanie a svedomitost' sú orientované na organizáciu (Ilies et al., 2009).

Príčiny, prečo sú zamestnanci ochotní správat' sa v zhode s OCB sú rôznorodé. Výskum sa doposial' orientoval na 4 hlavné kategórie - individuálne charakteristiky zamestnancov, charakter úloh, charakteristiky organizácie a správanie lídra (Podsakoff et al., 2000). Konkrétne, výskumy zistili, že predovšetkým spokojnost', zaviazanost', organizačná spravodlivost', rozvoj kariéry, vek, rod a osobnost' zamestnanca, motivácia a správanie lídra sú vo významnom, tesnom vzt'ahu s OCB (pozri napr. Dirican \& Erdil, 2016; Mohammad, Habib, \& Zakaria, 2010; Moorman, 1991; Organ \& Lingl, 1995).

Z hl'adiska charakteru príspevku je pre nás najpodstatnejšia kategória individuálnych charakteristík zamestnancov a charakteristiky organizácie. Pre potreby aktuálneho výskumu bližšie ozrejmíme vzt’ah medzi OCB a vybranými socio-demografickými ukazovatel'mi (rod, vek) a organizačnou spravodlivost'ou.

Vzt'ah medzi OCB a rodom je ešte stále diskutabilný a výsledky sú nekonzistentné. Niektoré výskumy tento vzt’ah nepotvrdili (pozri napr. Podsakoff et al., 2000), naopak výsledky iných štúdií tento vzt'ah deklarovali (napr. Eagly, 2009; Kidder, 2002). Ženy majú tendenciu orientovat' OCB k ostatným jednotlivcom, zatial' čo muži ho orientujú k organizácii (Wanxian \& Weiwu, 2007). Vo všeobecnosti však ženy preukazujú vyššiu mieru OCB v porovnaní s mužmi (Eagly, 2009; Farrell \& Finkelstein, 2007; Kidder, 2002). Heilmanová a Chenová (2005) podotýkajú, že muži sú vo väčšej miere oceňovaní za OCB v porovnaní so ženami, 
pretože u žien prevláda istý stereotypný predpoklad, že je pre nich prirodzené a bežné správat' sa prosociálne až altruisticky (t.j. u mužov je to istý druh „výnimočnosti“). U ostatných sociodemografických ukazovatel'ov (ako zručnosti, vedomosti, profesionálna orientácia alebo odpracované roky) sa nepotvrdil signifikantný vzt'ah k OCB (Podsakoff et al., 2000).

Wagnerová a Rush (2000) tvrdia, že u starších zamestnancov je vyššia pravdepodobnost' OCB aktivít v porovnaní s mladšími zamestnancami. Taktiež Kuehn a Al-Busaid (2002) objavili signifikantný vzt'ah medzi vekom a OCB. Cohen (1993) predpokladá, že vek je dôležitým prediktorom OCB, pretože sa považuje za hlavný ukazovatel' naakumulovaných investícií jedinca, o ktoré by mohol príst', ak by organizáciu opustil.

Organizačná spravodlivost' môže byt' definovaná ako subjektívne hodnotenie férovosti v organizácii. Organizačná spravodlivost' je kl'účovým faktorom, ktorý je spojený s úspechom každej organizácie. Ak má organizácia za ciel' udržat' svojich zamestnancov spokojných, oddaných a lojálnych, musí byt' vo svojom systéme spravodlivá (Colquitt, Greenberg, \& Zapata-Phelan, 2005). Samotná štruktúra organizačnej spravodlivosti sa v priebehu rokov viackrát menila. Rané štúdie nazerali na organizačnú spravodlivost' ako na fenomén, ktorý odráža v prvom rade mieru férovosti rozhodovacieho procesu, a v druhom rade mieru férovosti del'by zdrojov (Greenberg, 1987). Organizačná spravodlivost' tak bola chápaná $\mathrm{v}$ dvojdimenzionálnom rozmere, konkrétne $\mathrm{v}$ zmysle dimenzie procedurálnej spravodlivosti (procedúra, rozhodovací proces) a distributívnej spravodlivosti (del'ba zdrojov) (Rovenská, 2016). Neskorší výskum však ukázal, že l'udia hodnotia aj iné aspekty spravodlivosti ako tie distributívne a procedurálne, konkrétne aspekty spravodlivosti spojené s interakčným procesom. Na základe týchto zistení bol pôvodný dvojdimenzionálny model organizačnej spravodlivosti rozšírený o d'alšiu dimenziu - interaktívnu spravodlivost', ktorá odkazuje na vnímanie spravodlivosti v rovine zaobchádzania s človekom ako s l'udskou bytost'ou - dôstojne, s rešpektom a zdvorilost'ou (Judge, Scott, \& Ilies, 2006). Koncept interaktívnej spravodlivosti sa ale zdal príliš všeobecný a široký. Na základe daného predpokladu sa Colquitt (2001) rozhodol rozlíšit' $\mathrm{v}$ rámci interaktívnej spravodlivosti ešte dve subdimenzie (interpersonálna a informačná spravodlivost'). Podl'a spomenutého autora interpersonálna spravodlivost' odráža mieru rešpektu a korektnosti, ktorú využíva autorita pri implementácii procedúr a informačná spravodlivost' zase odráža mieru opodstatnenia, oprávnenosti a pravdivosti či úprimnosti, ktorá je poskytnutá počas procedúr. Zhrnutím uvedených informácií sa dostávame k záveru, že v súčasnosti vedecká obec akceptuje 4-dimenzionálny model organizačnej spravodlivosti navrhnutý Colquittom (2001), ktorý popisuje nasledujúce dimenzie: (1) procedurálna spravodlivost' (vnímaná férovost' procedúry, predovšetkým sa sústred'uje na proces, akým sa robia rozhodnutia), (2) distributívna spravodlivost' (hodnotenie pomeru vkladov a výnosov), (3) interpersonálna spravodlivost' (miera rešpektu a korektnosti, ktorú využíva autorita pri implementácii procedúr) a (4) informačná spravodlivost' (úroveň opodstatnenia, oprávnenosti, pravdivosti a úprimnosti, ktorá je poskytnutá počas procedúr).

Transformovaním teoretických charakteristík jednotlivých dimenzií organizačnej spravodlivosti do praktickej roviny je možné postrehnút', že v pracovnom prostredí zamestnanci jednak hodnotia, či odmeny, ktoré dostávajú, zodpovedajú ich vkladom do organizácie alebo, či zodpovedajú odmenám, ktoré získali ich kolegovia (Adams, 1963; Leventhal, 1976). Taktiež posudzujú mieru spravodlivosti rozhodovacích postupov používaných autoritami organizácie, 
aby zistili, či sú tieto postupy konzistentné, objektívne, presné, opravitel'né a reprezentujú ich záujmy a názory (Greenberg, 1987; Thibaut \& Walker, 1975). V neposlednom rade hodnotia i interpersonálnu rovinu v rámci implementácie procedúr autorít organizácie (Bies \& Moag, 1986; Greenberg, 1993).

Organizačná spravodlivost' podporuje pozitívny postoj voči pracovnej spokojnosti, záväzku a dôvere, a následne vytvára zdravé, konštruktívne, profesionálne a interpersonálne správanie (Baldwin, 2006).

Jeden z najviac študovaných korelátov organizačnej spravodlivosti je práve OCB a jeho dimenzie. Štúdium vzt'ahu medzi OCB a organizačnou spravodlivost'ou ukázalo, že všetky dimenzie organizačnej spravodlivosti súvisia s aktivitami OCB. Vnímanie procedurálnej spravodlivosti je spojené s OCB (Organ, Podsakoff, \& MacKenzie, 2006). Inými slovami, vnímanie procedurálnej spravodlivosti sa spája s istými prvkami prosociálneho správania prejavujúcimi sa v organizácii. Tento vzt’ah sa potvrdil aj v d'alších štúdiách (pozri napr. Iqbal, Aziz, \& Tasawar, 2012; Jafari \& Bidarian, 2012; Zeinabadi \& Salehi, 2011). Procedurálna spravodlivost' je predpokladom zdroja spokojnosti a pozitívneho hodnotenia organizácie, resp. zvyšuje pravdepodobnost', že ak zamestnanci na pracovisku vnímajú procedurálne aspekty organizačnej spravodlivosti, tak sú ochotní podriadit' svoje vlastné krátkodobé individuálne záujmy záujmom organizácie alebo pracovnej skupiny (Lind \& Tyler, 1988). Spector a Che (2014) zistili, že distributívna spravodlivost' pozitívne koreluje s OCB. Iné výskumy (Ertürk, 2007; Oren et al., 2013) ukázali, že ak zamestnávatelia zaobchádzajú so svojimi zamestnancami spravodlivo je viac pravdepodobné, že zamestnanci budú dodržiavat' organizačné pravidlá a budú preukazovat' viac nadšenia voči svojej práci a organizácii. Zamestnanci budú implementovat' aktivity spojené s OCB v organizácii iba vtedy, ak s nimi bude manažment zaobchádzat' spravodlivo. Predpokladá sa, že spravodlivé zaobchádzanie má za následok otvorené sociálne vzt'ahy, pričom tieto typy vzt'ahov budú mat' za následok pocit záväzku zamestnanca voči nadriadenému alebo organizácii, výsledkom čoho bude OCB (Cropanzano, Bowen, \& Gilliland, 2007; Williams, Pitre, \& Zainuba, 2002).

Štúdia od Zhaoa, Penga a Chena (2014) konštatuje, že vnímanie spravodlivých odmien za vstupy súvisiace s prácou, môže mat' s väčšou pravdepodobnost'ou za následok, že sa zamestnanci budú cítit' povinní reagovat' určitým dobrovol'ným správaním, akým je OCB. Podobne, zamestnanci, ktorí budú vnímat', že ich organizácia je spravodlivá z hl'adiska rozhodovacích postupov prejavia s väčšou pravdepodobnost' OCB. Mimo iného, ak budú zamestnanci vnímat', že im organizácia umožnila vyjadrit' svoje myšlienky z hl'adiska interpersonálnej komunikácie, budú s väčšou pravdepodobnost’ou vykonávat' aktivity OCB. Vzájomné vzt’ahy medzi jednotlivými dimenziami organizačnej spravodlivosti a OCB potvrdzujú aj Nandan a Azim (2015).

Riouxová a Penner (2001) dodávajú, že zamestnanci sa angažujú v rámci OCB, pretože vnímajú, že organizácia im poskytla dobrú prácu a zaobchádza s nimi spravodlivo. Títo l’udia cítia povinnost' odplatit' sa organizácii za všetko, čo im poskytla. Majú pocit zadlženosti voči organizácii a pokúšajú sa o splatenie prostredníctvom vykonávania aktivít OCB.

Téma organizačného občianskeho správania je aktuálna, avšak v rámci tuzemskej literatúry málo rozpracovaná. Predkladaný príspevok má preto zámer vyplnit' toto prázdne miesto vo výskume a ponúknut' hodnotný prehl'ad výskumných zistení a možností pre d’alší rozvoj 
predmetnej problematiky. Vychádzajúc zo zámeru príspevku a na základe preštudovania odbornej literatúry a uvedených teoretických východísk si kladieme tieto výskumné otázky:

- Aká je miera OCB vybraných zamestnancov?

- V akej miere vnímajú vybraní zamestnanci spravodlivost' v ich organizácii?

- Ktoré vybrané faktory sú signifikantnými prediktormi OCB?

Ciel'om predkladaného príspevku je identifikovat' (1) mieru OCB a jeho dimenzií, (2) mieru organizačnej spravodlivosti a jej dimenzií. Ďalším ciel'om je analyzovat' a vysvetlit' charakter vzt’ahu medzi (1) OCB, dimenziami organizačnej spravodlivosti a vybranými sociodemografickými ukazovatel'mi (rod, vek, odpracované roky v organizácii), (2) OCB-O, dimenziami organizačnej spravodlivosti a vybranými socio-demografickými ukazovatel'mi (rod, vek, odpracované roky v organizácii), (3) OCB-I, dimenziami organizačnej spravodlivosti a vybranými socio-demografickými ukazovatel'mi (rod, vek, odpracované roky v organizácii).

\section{Metóda}

\section{Výskumnýs súbor}

Do výskumu bolo zapojených 210 respondentov. Výskumný súbor tvorilo 116 žien $(55,2 \%)$ a 94 mužov (44,8\%). Vek opýtaných respondentov sa pohyboval od 18 do 58 rokov, pričom priemerný vek bol 34,82 rokov $(\mathrm{SD}=10,97)$. Každý z opýtaných respondentov udržiaval trvalý pracovný pomer v určitej organizácii v rámci Slovenskej republiky. Konkrétne, 57 respondentov $(54,3 \%)$ pracovalo pre organizáciu súkromného sektora, 44 (41,9 \%) bolo zamestnaných $\mathrm{v}$ organizácii verejného sektora a pre neziskovú organizáciu pracovali 4 respondenti $(3,8 \%)$. Priemerný počet odpracovaných rokov v organizácii bol 6,27 roka (SD = 5,75). Výskumný súbor bol získaný na základe príležitostného výberu založeného na dostupnosti osôb a ich ochote podiel'at' sa na výskume a so všetkými účastníkmi výskumu bolo zaobchádzané v zhode s etickými princípmi výskumu. Potencionálni respondenti boli do výskumu pozývaní prevažne prostredníctvom komunikačného kanála sociálnych sietí a emailu s webovým odkazom na dotazník.

\section{Výskumné nástroje}

$\mathrm{Na}$ meranie organizačného občianskeho správania bol využitý dotazník Organizational Citizenship Behavior Checklist (OCB-C) (Spector \& Fox, 2011). Metodika je určená na posúdenie frekvencie organizačného občianskeho správania zamestnancov na pracovisku. Pôvodný dotazník Organizational Citizenship Behavior Checklist (OCB-C) obsahoval 42 položiek, neskôr bol skrátený na 36 položiek a napokon bol zúžený na 20 položiek. Dotazník je možné použit' dvomi spôsobmi. Pri prvom spôsobe zamestnanci posudzujú svoje vlastné správanie v práci. Pri druhom spôsobe je správanie zamestnancov hodnotené inými, ako napríklad ich nadriadenými alebo kolegami v práci. Na účely vlastného výskumu bola zvolená prvá alternatíva, pri ktorej respondenti - zamestnanci posudzovali sami svoje správanie v práci. Vo výskume bola využitá 20-položková verzia dotazníka (Podsakoff et al., 1990; slovenskú verziu dotazníka, ktorý bol využitý vo výskume, vytvorili Schraggeová \& Rošková, 2016). Dotazník je zameraný na dve hlavné formy $\mathrm{OCB}$, a to na správanie zamerané na organizáciu 
(OCB-O) a správanie zamerané na jednotlivca, resp. kolegov (OCB-I). Respondenti sa vyjadrovali, ako často vykonávajú určité aktivity v ich súčasnom zamestnaní na 5-stupňovej Likertovej škále (1 - nikdy, 2 - občas, 3 - raz alebo dvakrát za mesiac, 4 - raz alebo dvakrát za týždeň, 5 - každý deň) (napr. vyzdvihnutie jedla pre ostatných v práci; ponúkanie návrhov na zlepšenie pracovného prostredia; vzdanie sa prestávky na jedlo a odpočinok z dôvodu snahy dokončit' prácu). Úlohou respondentov bolo odpovedat' na položky v podobe tvrdení a zároveň na to, ako často vykonávajú dané správanie. Celkové skóre OCB je potom súčtom odpovedí na všetky položky. Skóre pre jednotlivé formy je súčtom odpovedí, ktoré sa zameriavajú na príslušné správanie smerom k organizácii (OCB-O - 6 položiek ) a smerom ku kolegom (OCB-I - 6 položiek). Hodnoty vnútornej konzistencie boli nasledovné: (1) OCB 0,93, (2) OCB-O 0,82, (3) OCB-I 0,80.

Na meranie organizačnej spravodlivosti bola využitá škála Organizational Justice Scale (Colquitt, 2001). Škála sa nezameriava priamo na vnímanie organizačnej spravodlivosti, je orientovaná na organizačnú spravodlivost' nepriamo - cez hodnotenie aspektov spravodlivosti, ako napríklad nezaujatost', konzistentnost', poskytovanie informácií a pod. Autor dotazníka vychádzal zo zistenia, že „nepriame hodnotenie“ poskytuje viac informácií o miere organizačnej spravodlivosti. Zároveň dodáva, že takéto meranie organizačnej spravodlivosti silnejšie koreluje s rôznymi typmi organizačného správania. Škála samostatne meria procedurálnu, distributívnu, interpersonálnu a informačnú spravodlivost', pričom každá dimenzia obsahuje niekol'ko položiek. Procedurálna spravodlivost' obsahuje 7 položiek, ktoré sa týkajú pracovných postupov využívaných v zamestnaní, napríklad „,Do akej miery môžete ovplyvňovat' pracovné postupy?“. Distributívna spravodlivost' je zastúpená 4 položkami, ktoré sa týkajú del'by odmien, benefitov v práci, napríklad „Do akej miery sú Vaše odmeny primerané práci, ktorú ste dokončili?““. Interpersonálnu spravodlivost' tvoria 4 položky, ktoré sa týkajú autorít v práci a ich zaobchádzania so zamestnancami, napríklad „Do akej miery s Vami nadriadení zaobchádzajú dôstojne?“. Informačná spravodlivost’ obsahuje 5 položiek, ktoré sa zameriavajú na hodnotenie miery informovanosti poskytovanej autoritami v práci, napríklad „Do akej miery Vám nadriadení dôkladne vysvetlia pracovné postupy?“. Respondenti vyjadrujú mieru (ne)súhlasu k jednotlivým výrokom na 5-bodovej škále (1- do vel’mi malej miery, 2 - do malej miery, 3 - neviem, 4 - do vel'kej miery, 5 - do vel'mi vel'kej miery). Skóre sa počíta pre každú dimenziu organizačnej spravodlivosti samostatne. Platí, že čím je vyššie skóre, tým je viac vnímaná určitá dimenzia organizačnej spravodlivosti. Hodnoty vnútornej konzistencie boli nasledovné: (1) procedurálna spravodlivost' 0,90, (2) distributívna spravodlivost' 0,94, (3) interpersonálna spravodlivost' $0,93,(4)$ informačná spravodlivost' $0,92$.

\section{Výsledky}

\section{OCB a jeho dimenzie}

Súčastou OCB je participácia na aktivitách či činnostiach, ktoré nie sú formálnou súčast’ou popisu práce zamestnanca, ide o akúsi „prácu“ navyše. Analýza údajov OCB ukázala, že v priemere respondenti vykazovali nižšiu mieru daného druhu prosociálneho správania, nakol'ko priemerné vážené skóre $\mathrm{OCB}$ dosiahlo hodnotu 2,28 bodov ( $\mathrm{SD}=0,67)$, teda prenesením hodnoty do verbálnej podoby môžeme tvrdit', že opýtaní respondenti len občas vykonávali tento druh aktivít. 
Obdobne na tom boli aj samotné formy OCB. Aktivity spojené s OCB-O ( $\mathrm{M}=2,26 ; \mathrm{SD}=0,74)$ ako aj s OCB-I $(\mathrm{M}=2,52 ; \mathrm{SD}=0,76)$ respondenti vykonávali občas (metodika využívala 5bodovú škálu: 1 - nikdy, 2 - občas, 3 - raz alebo dvakrát za mesiac, 4 - raz alebo dvakrát za týždeň, 5 - každý deň).

V rámci hl'adania rodových rozdielov v kontexte OCB sa preukázal štatisticky významný rodový rozdiel výlučne v prípade OCB-I $\left(\mathrm{t}_{(208)}=2,68 ; \mathrm{p}=0,008\right)$, pričom vyššiu mieru OCB-I vykazovali muži. Konkrétne údaje sú uvedené v tabul'ke 1.

Tabul'ka 1 Rodové rozdiely v rámci OCB

\begin{tabular}{|c|c|c|c|c|c|}
\hline & & $\mathrm{M}$ & SD & $\mathrm{t}$ & $\mathrm{p}$ \\
\hline \multirow{2}{*}{ OCB } & $\overline{\text { muž }}$ & 2,32 & 0,71 & \multirow{2}{*}{0,79} & \multirow{2}{*}{0,433} \\
\hline & žena & 2,24 & 0,64 & & \\
\hline \multirow{2}{*}{ OCB-O } & $\overline{\text { muž }}$ & 2,29 & 0,80 & \multirow{2}{*}{0,59} & \multirow{2}{*}{0,552} \\
\hline & žena & 2,23 & 0,69 & & \\
\hline \multirow{2}{*}{ OCB-I } & $\overline{\text { muž }}$ & 2,67 & 0,79 & \multirow{2}{*}{2,68} & \multirow{2}{*}{0,008} \\
\hline & žena & 2,40 & 0,71 & & \\
\hline
\end{tabular}

Poznámka - OCB (organizačné občianske správanie), OCB-O (organizačné občianske správanie zamerané na organizáciu), OCB-I (organizačné občianske správanie zamerané na jednotlivca)

\section{Organizačná spravodlivost’ a jej dimenzie}

Spravodlivost', ktorá je vnímaná zamestnancami v organizáciách, sa môže vzt'ahovat' k rôznym aspektom, od del'by benefitov cez rozhodovací proces až po mieru informácií, ktoré sú vzájomne zdiel'ané. ANOVA pre opakované merania ukázala, že existuje štatisticky významný rozdiel medzi úrovňami meranej premennej pre hlavný faktor „organizačná spravodlivost'“،, pričom $\mathrm{F}(2,47 ; 515,35)=79,16 ; \mathrm{p}<0,001$. Inými slovami, rozdiel $\mathrm{v}$ hodnotách jednotlivých dimenzií vo faktore „organizačná spravodlivost'“ nebol náhodný. Na základe Bonferroniho post hoc testu sa potvrdil signifikantný rozdiel medzi dimenziami: PS x DS ( $p<0,001)$, PS x IPS ( $p$ $<0,001)$, PS x IFS ( $<<0,001)$, DS x IPS ( $p<0,001)$, DS x IFS ( $<<0,001)$. Najvyššie priemerné vážené skóre dosiahla dimenzia IPS $(\mathrm{M}=3,78 ; \mathrm{SD}=1,05)$. Môžeme konštatovat', že respondenti vnímali mieru rešpektu a korektnosti do vel'kej miery ako spravodlivú. Konkrétne údaje sú uvedené v tabul'ke 2 . 
Tabul'ka 2 Deskriptívne údaje organizačnej spravodlivosti (zoradené zostupne)

\begin{tabular}{|l|c|c|c|c|}
\hline & MIN & MAX & M & SD \\
\hline IPS & 1,00 & 5,00 & 3,78 & 1,05 \\
\hline IFS & 1,00 & 5,00 & 3,69 & 1,09 \\
\hline PS & 1,29 & 5,00 & 3,25 & 0,91 \\
\hline DS & 1,00 & 5,00 & 2,99 & 1,16 \\
\hline
\end{tabular}

Poznámka - IPS (interpersonálna spravodlivost'), IFS (informačná spravodlivost'), PS (procedurálna spravodlivost'), DS (distributívna spravodlivost')

\section{OCB, organizačná spravodlivost' a vybrané socio-demografické ukazovatele}

Vychádzajúc z teoretických východísk a už uskutočnených štúdií bolo našou prioritou overit' potencionálnu súvislost' medzi $\mathrm{OCB}$, organizačnou spravodlivost'ou a vybranými sociodemografickými ukazovatel'mi (rod, vek, odpracované roky v organizácii). V nasledujúcej časti sa preto zameriame na predikované premenné OCB, OCB-O a OCB-I, kde ako prediktor figurujú 4 dimenzie organizačnej spravodlivosti a 3 socio-demografické ukazovatele (rod, vek, odpracované roky v organizácii).

V prvom lineárnom modeli dokázali prediktory dokopy vysvetlit' $34,4 \%$ rozptylu OCB. Z nezávisle premenných, výlučne dimenzie organizačnej spravodlivosti (PS p < ,001; DS $p=0,006$; IPS $p=0,001$; IFS $p=0,001$ ) predikovali OCB (tabul'ka 3).

Tabul'ka 3 Lineárny model vysvetl’ujúci OCB

\begin{tabular}{|l|c|c|c|c|c|}
\hline & \multicolumn{5}{|c|}{ OCB F(7, 202) $=15,13 ; \mathrm{p}<, 001$} \\
\hline PS & $B$ & $S . E$. & $\beta$ & $t$ & $P$ \\
\hline DS & 0,23 & 0,06 & 0,32 & 3,57 & $<0,001$ \\
\hline IPS & 0,14 & 0,05 & 0,24 & 2,78 & 0,006 \\
\hline IFS & 0,24 & 0,07 & 0,38 & 3,40 & 0,001 \\
\hline rod & $-0,22$ & 0,07 & $-0,35$ & $-3,29$ & 0,001 \\
\hline vek & 0,02 & 0,08 & 0,02 & 0,27 & 0,787 \\
\hline $\begin{array}{l}\text { odpracované } \\
\text { roky v org. }\end{array}$ & $-0,01$ & 0,01 & $-0,10$ & $-1,29$ & 0,197 \\
\hline
\end{tabular}

Poznámka - PS (procedurálna spravodlivost'), DS (distributívna spravodlivost'), IPS (interpersonálna spravodlivost'), IFS (informačná spravodlivost'), OCB (organizačné občianske správanie) 
V druhom lineárnom modeli kombinácia prediktorov dokopy vysvetl'ovala 40,6 \% rozptylu OCB-O. Z nezávisle premenných, dimenzie organizačnej spravodlivosti (PS p < 0,001; DS $\mathrm{p}=0,001$; IPS $\mathrm{p}=0,001$; IFS $\mathrm{p}<0,001)$ a odpracované roky $\mathrm{v}$ organizácii $(\mathrm{p}=0,028)$ predikovali OCB-O (tabul'ka 4).

Tabul'ka 4 Lineárny model vysvetl'ujúci OCBO

\begin{tabular}{|l|c|c|c|c|c|}
\hline & \multicolumn{5}{|c|}{ OCB-O $\mathrm{F}(7,202)=19,72 ; \mathrm{p}<0,001$} \\
\hline PS & $B$ & $S . E$. & $\beta$ & $t$ & $P$ \\
\hline DS & 0,31 & 0,07 & 0,38 & 4,50 & $<0,001$ \\
\hline IPS & 0,17 & 0,05 & 0,27 & 3,25 & 0,001 \\
\hline IFS & 0,27 & 0,08 & 0,38 & 3,53 & 0,001 \\
\hline rod & $-0,27$ & 0,07 & $-0,39$ & $-3,79$ & $<0,001$ \\
\hline vek & 0,07 & 0,08 & 0,05 & 0,83 & 0,408 \\
\hline $\begin{array}{l}\text { odpracované } \\
\text { roky v org. }\end{array}$ & $-0,002$ & 0,01 & $-0,03$ & $-0,40$ & 0,692 \\
\hline
\end{tabular}

Poznámka - PS (procedurálna spravodlivost'), DS (distributívna spravodlivost'), IPS (interpersonálna spravodlivost'), IFS (informačná spravodlivost'), OCB-O (organizačné občianske správanie zamerané na organizáciu)

Kombinácia prediktorov v poslednom lineárnom modeli spolu dokázala vysvetlit' $28,1 \%$ rozptylu OCB-I. Z nezávisle premenných, PS ( $<<0,001)$ a rod $(\mathrm{p}=0,032)$ predikovali OCB-I (tabul'ka 5). V rámci daného výskumného súboru, ženy skórovali o 0,21 jednotiek nižšie na škále OCB-I. Výsledok môže indikovat', že vo všeobecnosti ženy vykonávali nižší počet dobrovol'ných aktivít spojených s OCB-I.

Tabul'ka 5 Lineárny model vysvetl'ujúci OCB-I

\begin{tabular}{|l|c|c|c|c|c|}
\hline & \multicolumn{5}{|c|}{ OCB-I F(7, 202) $=11,30 ; \mathrm{p}<0,001$} \\
\hline PS & $B$ & S.E. & $\beta$ & $t$ & $P$ \\
\hline DS & 0,31 & 0,08 & 0,37 & 3,99 & $<0,001$ \\
\hline IPS & 0,05 & 0,06 & 0,07 & 0,81 & 0,418 \\
\hline IFS & 0,16 & 0,08 & 0,23 & 1,92 & 0,057 \\
\hline rod & $-0,11$ & 0,08 & $-0,15$ & $-1,35$ & 0,179 \\
\hline vek & $-0,21$ & 0,10 & $-0,14$ & $-2,16$ & 0,032 \\
\hline $\begin{array}{l}\text { odpracované } \\
\text { roky v org. }\end{array}$ & $-0,01$ & 0,01 & $-0,12$ & $-1,39$ & 0,167 \\
\hline $\begin{array}{l}\text { Poznámka - PS (procedurálna spravodlivost'), DS (distributívna spravodlivost'), IPS (interpersonálna } \\
\text { spravodlivost'), IFS (informačná spravodlivost'), OCB-I (organizačné občianske správanie zamerané na } \\
\text { jednotlivca) }\end{array}$ & 0,02 & 0,01 & 0,11 & 1,30 & 0,193 \\
\end{tabular}




\section{Diskusia}

Výsledky ukázali, že pre opýtaných respondentov nebolo vel'mi typické prosociálne správanie prejavujúce sa či už vo vzt'ahu k ostatným kolegom alebo vo vzt’ahu k samotnej organizácii (OCB: $\mathrm{M}=2,28 ; \mathrm{SD}=0,67$; OCB-O: $\mathrm{M}=2,26 ; \mathrm{SD}=0,74$; OCB-I: $\mathrm{M}=2,52$; $\mathrm{SD}=0,76$ ). OCB aktivity vykonávali opýtaní respondenti len občas. Vysvetlenie daného výsledku je možné hladat' vo faktoroch ako je osobnost' zamestnanca, charakter a kvalita vzt'ahov na pracovisku či vel'kost' organizácie, v ktorej respondenti pracujú. V rámci možných vysvetlení je na mieste spomenút' aj kultúrny faktor. Individualistické kultúry (akou sa postupne stáva aj Slovensko v rámci Hofstedeho modelu dosahuje Slovensko 52 bodov v dimenzii individualizmuskolektivizmus; Andrijauskienė \& Dumčiuvienè, 2018) sa zameriavajú na nezávislost' a sebauspokojovanie, na osobný úspech, osobné ciele sú nadradené skupinovým ciel'om a osobné postoje sú nadradené skupinovým normám (de León \& Finkelstein, 2011). Rolová identita jedinca - zamestnanca, ktorá je podčiarknutá individualistickým prístupom, podporuje motívy a správanie skôr zamerané na vlastné Self než na ostatných či organizáciu.

Analýza rodových rozdielov v rámci OCB priniesla odlišné zistenia ako ostatná odborná literatúra, ktorá tvrdí, že ženy vykazujú vyššiu mieru OCB ako muži (Eagly, 2009; Farrell \& Finkelstein, 2007; Kidder, 2002). Naše výsledky nepreukázali signifikantné rodové rozdiely $\mathrm{v}$ OCB $\left(\mathrm{t}_{(208)}=0,79 ; \mathrm{p}=0,433\right)$, preto sa prikláňame $\mathrm{k}$ názoru iných štúdií, ktoré rovnako takýto rozdiel nezistili (Bukhari \& Ali, 2009; Chou \& Pearson, 2011). Zaujímavým zistením však bolo, že v priemere muži vykazovali vyššiu mieru OCB-I v porovnaní so ženami $\left(\mathrm{M}_{(\mathrm{muž})}=2,67\right.$; $\left.\mathrm{SD}=0,79 ; \mathrm{M}_{(\text {žena) }}=2,40 ; \mathrm{SD}=0,71 ; \mathrm{t}_{(208)}=2,68 ; \mathrm{p}=0,008\right)$. Heilmanová a Chenová (2005) uvádzajú, že muži sú vo väčšej miere oceňovaní za pomáhajúce správanie v porovnaní so ženami, pretože u žien prevláda istý stereotypný predpoklad, že je pre nich prirodzené a bežné správat' sa prosociálne až altruisticky (t.j. u mužov je to istý druh ,výnimočnosti““). Je možné sa domnievat', že ženy si túto situáciu a neférovost' uvedomujú, preto vedome potláčajú správanie zamerané na pomoc ostatným vnútri organizácie. Na strane druhej, je možné uvažovat' aj o hypotéze, že muži sa správajú prosociálne voči ostatným účelovo. Je známe, že muži sú ego-orientovaní a upriamujú sa na výsledky, úspech a status, preto sa môžu domnievat', že ak sa budú správat' v záujme pomoci ostatným kolegom (t.j. budú vykazovat' zvýšenú mieru OCB-I), všimne si to manažment, ktorý ich následne priamo či nepriamo ocení za toto správanie (napr. povýšenie, finančná odmena, pochvala atd’.). Motívom k vykonávaniu OCB nemusí byt' vždy len prosociálnost' (tzv. ,good soldier“), v niektorých prípadoch môže íst' len o snahu zaujat' manažment (tzv. ,good actor“) (Bourdage et al., 2012).

Výsledky d’alej priniesli zistenie, že interpersonálna dimenzia organizačnej spravodlivosti bola respondentmi hodnotená ako najvýznamnejšia. Interpersonálna spravodlivost' predstavuje férovost' zaobchádzania s druhou osobou v priebehu implementácie procedúr rozhodnutí (Bies \& Moag, 1986). Rešpekt a zdvorilost' potvrdzujú základné l'udské právo na osobnú integritu a potvrdzujú hodnotu človeka ako rovnocenného člena sociálnej skupiny (Tyler, 1989). Inými slovami, dodržiavanie princípov ako sú rešpekt a slušnost' signalizuje, že autority sa starajú o prosperitu a blaho vlastných zamestnancov (Colquitt \& Rodell, 2011). 7

Hlavným ciel'om výskumu bolo overit' charakter vzt'ahu medzi OCB, organizačnou spravodlivost'ou a vybranými socio-demografickými ukazovatel'mi. Dospeli sme k nasledujúcim záverom. Po prvé, všetky dimenzie organizačnej spravodlivosti sa ukázali ako 
signifikantné prediktory OCB, resp. OCB-O a OCB-I (OCB - všetky dimenzie organizačnej spravodlivosti, OCB-O - všetky dimenzie organizačnej spravodlivosti, OCB-I - PS). Po druhé, vybrané socio-demografické ukazovatele čiastočne predikovali OCB-O (odpracované roky v organizácii) a OCB-I (rod).

Naše výsledky podporujú aj zistenia iných štúdií (Oren et al., 2013; Organ, Podsakoff, \& MacKenzie, 2006; Spector \& Che, 2014), ktoré taktiež odhalili signifikantný vzt'ah medzi OCB a organizačnou spravodlivost'ou. Zamestnanci sa angažujú v rámci $O C B$, pretože vnímajú, že organizácia im poskytla dobrú prácu a zaobchádza s nimi spravodlivo. Títo l’udia cítia povinnost' odplatit' sa organizácii za všetko, čo im poskytla. Majú pocit zadlženosti voči organizácii a pokúšajú sa o splatenie prostredníctvom vykonávania aktivít OCB (Rioux \& Penner, 2001). PS ako prediktor OCB-I môže odkazovat' na samotnú podstatu procedurálnej spravodlivosti a jej konzekvencie. V rámci procedurálnej spravodlivosti nezáleží len na priamej kontrole procedúry, ktorá má viest' $\mathrm{k}$ rozhodnutiam, nemenej významný je tiež spôsob zaobchádzania s jedincom počas rozhodovania. Človek je l'udská bytost', ktorá síce potrebuje mat' dohl'ad nad udalost'ami, ktoré sa dejú v jej živote, ale táto kontrola je vždy zasadená do interaktívneho rámca. Inými slovami, človek je spoločenský tvor konajúci v interakcii s druhými. Teda, na jednej strane stojí subjektívna kontrola nad procedúrou, vychádzajúca z vlastných schopností, a na strane druhej objektívne premenné sociálnej skupiny (možnost' vyjadrit’ svoj názor, rešpekt, uznanie a i.), v ktorej sa jednotlivec nachádza (Rovenská, 2017). Ak sa jedinec - zamestnanec sústred'uje na dlhodobý vzt’ah s pracovnou skupinou, môže hodnotit' spravodlivost' na základe informácií o jeho postavení v skupine, ktoré vychádzajú z uskutočňovaných procedúr (Sunshine \& Heuer, 2002). Je preto možné domnievat' sa, že l'udia si osvojujú hodnoty spravodlivosti, ktoré prevyšujú osobné záujmy, výsledky spravodlivosti vytvárajú podstatu identity a vysoko ovplyvňujú vzt’ah medzi jednotlivcom a skupinou (Sousa \& Vala, 2002).

Odpracované roky v organizácii môžu fungovat’ ako signifikantný prediktor OCB-O, pretože čím dlhšie sú zamestnanci súčast'ou istej organizácie, tým sú vo väčšej miere oboznámení s organizačnými pravidlami, politikou organizácie, postupmi, jej štruktúrou a kultúrou. Vo väčšej miere si uvedomujú ciele organizácie a to, ako ich dosiahnut' a vo väčšej miere sú zaviazaní $\mathrm{k}$ dosiahnutiu týchto ciel'ov a vyvíjajú extra úsilie, ktoré presahuje formálne požiadavky (Mohammad, Habib, \& Zakaria, 2010).

Ako už bolo uvedené, analýza rodových rozdielov v kontexte OCB priniesla zaujímavé poznanie, teda, že muži vo vyššej miere preukazovali OCB-I ako ženy. Táto skutočnost' sa následne pretavila aj do lineárneho modelu OCB-I, kde rod figuroval ako významný prediktor OCB-I. Tento vzt'ah, samozrejme, nie je prekvapujúci, nakol'ko aj iné štúdie odkazujú, že súvislost' medzi rodom a OCB skutočne existuje (Eagly, 2009; Kidder, 2002).

V rámci diskusie výsledkov je nutné spomenút' aj možné limity štúdie, ktoré mohli ovplyvnit’ charakter výsledkov, ale môžu naznačovat' budúce smerovanie výskumu. Po prvé, pre budúci výskum by bolo prínosné pracovat's väčším počtom respondentov zabezpečených náhodným výberom, čím by sa následne zlepšila aj výstižnost' lineárnych modelov. Po druhé, nezávisle premenné ozrejmili menšiu čast' celkovej variancie OCB, resp. OCB-O a OCB-I. Z daného dôvodu by bolo prínosné, aby sa v budúcnosti do modelu pridali d’alšie premenné, ktoré môžu 
mat' potencionálny súvis s OCB. Týmto krokom by sa zlepšila nielen celková validita modelov, ale tiež by sa zvýšila ich schopnost' vysvetlit' varianciu OCB, resp. OCB-O a OCB-I.

Záverom diskusie je potrebné, ba až žiaduce zdôraznit' významnost' výsledkov v dvoch rovinách. Po prvé, ich významnost' pre vedeckú obec. Problematika OCB je málo riešená v rámci tuzemského výskumu. $\mathrm{V}$ tejto rovine sa priamo ukazuje medzera vo výskume, ktorá by mohla byt' vyplnená transferom poznatkov medzi odborníkmi aj na interdisciplinárnej úrovni pre poskytovanie konštruktívnych a kritických pripomienok $\mathrm{k}$ predmetnej problematike. Po druhé, významnost' pre prax. Poznatky vzt'ahujúce sa k zisteniam o neformálnom spôsobe správania sa zamestnancov, o ich práci „navyše“ pre kolegov či organizáciu, o vnímaní aspektov spravodlivosti v organizácii a vzájomnom prepojení týchto dvoch premenných, môžu byt' hodnotným zdrojom pre konkrétne organizácie. Organizácie by mali vnímat' tento druh správania, vyzdvihnút' jeho hodnotu, podporovat' a rozvíjat' ho, pretože môže mat' dosah na celkovú kvalitu organizácie na všetkých jej úrovniach, v rámci celkovej štruktúry a dynamiky.

\section{Záver}

Príspevok sa zaoberal problematikou OCB vo vzt’ahu k organizačnej spravodlivosti a vybraným socio-demografickým premenným.

OCB je pre efektívne fungovanie organizácie ako celku prospešné a práve z tohto dôvodu vel'mi žiadané. Úlohou organizácie by malo byt' naṕl̆nanie požiadaviek zamestnancov a vytváranie funkčného a harmonického prostredia, v ktorom budú zamestnanci ochotní vykazovat' OCB. To, či sa zamestnanec rozhodne prejavovat' OCB do značnej miery ovplyvňuje subjektívne vnímanie miery spravodlivosti, ktorá vládne v samotnej organizácii. Štúdie potvrdzujú, že prostredníctvom organizačnej spravodlivosti sa v zamestnaní vytvára väčšia dôvera medzi manažmentom a zamestnancami. Táto skutočnost' má za následok napríklad to, že sa v práci znižujú konflikty, a naopak zlepšuje sa tímová práca a celková atmosféra na pracovisku.

Výskum sa v danej problematike musí rozvíjat', nakol'ko je nutné sa hlbšie zamerat' na analýzu nielen príčin OCB, ale tiež na definovanie dôsledkov daného typu správania. Výskum OCB je v rámci Slovenska málo rozvinutý, preto je potrebné preskúmat' rôznorodé dispozičné a situačné faktory, ktoré sa môžu významnou mierou podiel'at' na OCB, či už v zmysle sociodemografických ukazovatel'ov (rod, vek, kultúrny kontext), ale tiež faktorov ako motivácia (Ahmed \& Khan, 2016), osobnostné črty (Bourdage et al., 2012), morálne zdôvodňovanie (Bonner, Greenbaum, \& Mayer, 2014; Čopková, 2016) alebo štýly vedenia (Decoster et al., 2014). Nakol'ko uskutočnená štúdia poukázala, že rôzne formy OCB sú vo vzt'ahu k rôznym prediktorom, túto skutočnost' je potrebné brat' do úvahy pri budúcom výskume. Ako už bolo spomenuté, dôležité nie sú len príčiny $\mathrm{OCB}$, ale aj to, aké dôsledky OCB prináša pre jednotlivca a aj pre samotnú organizáciu, napríklad miera spokojnosti (Foote \& Tang, 2008; Köverová, 2019), výkon zamestnancov (Nielsen, Hrivnak, \& Shaw, 2009), kohezivita pracovnej skupiny (Apaydin \& Şirin, 2016) a pod. Získané informácie by tak dokázali obohatit' odbornú literatúru o nové poznatky z oblasti skúmania organizačného občianskeho správania, jeho ascendentov a dôsledkov. 


\section{Literatúra}

Adams, J. S. (1963). Toward an understanding of inequity. Journal of Abnormal and Social Psychology, 67(5), 422-436.

Ahmed, S. W., \& Khan, T. (2016). Does motivation lead to organizational citizenship behavior? - A theoretical review. Global Journal of Management and Business Research: A Administration and Management, 16(7), 43-49.

https://journalofbusiness.org/index.php/GJMBR/article/view/2004/1906

Andrijauskienè, M., \& Dumčiuvienè, D. (2018). National culture as a determinant of firms' innovative performance. Forum Scientiae Oeconomia, 6(1), 47-68.

Apaydin, C., \& Şirin, H. (2016). The relationship between organizational citizenship behavior, group cohesiveness and workplace deviance behavior of Turkish teachers. International Education Studies, 9(10), 58-69. https://files.eric.ed.gov/fulltext/EJ1116062.pdf

Baldwin, S. (2006). Organizational justice. Briton: Institute for Employment Studies, University of Sussex Campus.

Bies, R. J., \& Moag, J. F. (1986). Interactional justice: Communication criteria of fairness. In R. J. Lewecki, B. H. Sheppard, \& M. H. Bazermann (Eds.), Research on negotiations in organizations (pp. 43-55). Greenwich: JAI Press.

Bonner, J. M., Greenbaum, R. L., \& Mayer, D. M. (2014). My boss is morally disengaged: The role of ethical leadership in explaining the interactive effect of supervisor and employee moral disengagement on employee behaviors. Journal of Business Ethics, 137(4), 731-742. https://doi.org/10.1007/s10551-014-2366-6

Bourdage, J. S., Lee, K., Lee, J. H., \& Shin, K. H. (2012). Motives for organizational citizenship behavior: Personality correlates and coworker ratings of OCB. Human Performance, 25(3), 179200. https://doi.org/10.1080/08959285.2012.683904

Bukhari, Z. U., \& Ali, U. (2009). Relationship between organizational citizenship behavior and counterproductive work behavior in the geographical context of Pakistan. International Journal of Business and Management, 4(1), 85-92. http://citeseerx.ist.psu.edu/viewdoc/download?doi=10.1.1.981.7065\&rep=rep1\&type=pdf\#page=86

Cohen, A. (1993). Age and tenure in relation to organizational commitment: Meta Analysis. Basic and Applied Social Psychology, 14(2), 143-159./doi.org/10.1207/s15324834basp1402_2

Colquitt, J. A. (2001). On the dimensionality of organizational justice: A construct validation of a measure. Journal of Applied Psychology, 86(3), 386-400.

Colquitt, J. A., Greenberg, J., \& Zapata-Phelan, C. P. (2005). What is organizational justice? A historical overview. In J. Greenberg, \& J. A. Colquitt (Eds.), The Handbook of Organizational Justice (pp. 3-56). Mahwah, NJ: Erlbaum.

Colquitt, J. A., \& Rodell, J. B. (2011). Justice, trust, and trustworthiness: A longitudinal analysis integrating three theoretical perspectives. Academy of Management Journal, 54(6), 1183-1206. https://doi.org/10.5465/amj.2007.0572

Cropanzano, R., Bowen, D. E., \& Gilliland, S.W. (2007). The management of organizational justice. Justice Academy of Management Perspectives, 21(4), 34-48. https://doi.org/10.5465/amp.2007.27895338

Čopková, R. (2016). Morálne zdôvodňovanie v kontexte na ciel' orientovaného správania. Človek a spoločnost', 19(3), 9-18. http://www.clovekaspolocnost.sk/jquery/pdf.php?gui=RN437V4ZLN3CVSMGCUIJG622T

De León, M. C. D., \& Finkelstein, M. A. (2011). Individualism/collectivism and organizational citizenship behavior. Psicothema, 23(3), 401-406. https://www.unioviedo.net/reunido/index.php/PST/article/view/9078/8942

Decoster, S., Stouten, J., Camps, J., \& Tripp, T. M. (2014). The role of employees' OCB and leaders' hindrance stress in the emergence of self-serving leadership. The Leadership Quarterly, 25(4), 647-659. https://doi.org/10.1016/j.leaqua.2014.02.005 
Dirican, A. H., \& Erdil, O. (2016). An exploration of academic staff's organizational citizenship behavior and counterproductive work behavior in relation to demographic characteristics. Procedia - Social and Behavioral Sciences, 235, 351-360. https://doi.org/10.1016/j.sbspro.2016.11.043

Eagly, A. H. (2009). The his and hers of prosocial behavior: An examination of the social psychology of gender. American Psychologist, 64(8), 644-658.

Ertürk, A. (2007). Increasing organizational citizenship behaviour of Turkish academicians: Mediating role of trust in supervisor on the relationship between organizational justice and citizenship behaviors. Journal of Managerial Psychology, 22(3), 257-270. https://doi.org/10.1108/02683940710733089

Farrell, S. K., \& Finkelstein, L. M. (2007). Organizational citizenship behavior and gender: Expectations and attributions for performance. North American Journal of Psychology, 9(1), 8195.

Foote, D. A., \& Tang, T. L. P. (2008). Job satisfaction and organizational citizenship behavior (OCB): Does team commitment make a difference in self-directed teams? Management Decision, 46(6), 933-947. https://doi.org/10.1108/00251740810882680

Greenberg, J. (1987). A taxonomy of organizational justice theories. The Academy of Management Review, 12(1), 9-22. https://doi.org/10.5465/amr.1987.4306437

Greenberg, J. (1993). Stealing in the name of justice: Informational and interpersonal moderators of theft reactions to underpayment inequity. Organizational Behavior and Human Decision Processes, 54, 81-103. https://doi.org/10.1006/obhd.1993.1004

Heilman, M. E., \& Chen, J. J. (2005). Same behaviour, different consequences: Reactions to men's and women's altruistic citizenship behavior. Journal of Applied Psychology, 90(3), 431-441. https://doi.org/10.1037/0021-9010.90.3.431

Chou, S. Y., \& Pearson, J. (2011). A demographic study of information technology professionals' organisational citizenship behavior. Journal of Management Research, 3(2), 1-15. https://doi.org/10.5296/jmr.v3i2.625

Ilies, R., Fulmer, I. S., Spitzmuller, M., \& Johnson, M. D. (2009). Personality and citizenship behavior: The mediating role of job satisfaction. Journal of Applied Psychology, 94(4), 945-959.

Iqbal, H. K., Aziz, U., \& Tasawar, A. (2012). Impact of organizational justice on organizational behavior: An empirical evidence from Pakistan. World Applied Sciences Journal, 19(9), 13481354. https://doi.org/10.5829/idosi.wasj.2012.19.09.750

Jafari, P., \& Bidarian, S. (2012). The relationship between organizational justice and organizational citizenship behavior. Procedia - Social and Behavioral Sciences, 47, 1815-1820. https://doi.org/10.1016/j.sbspro.2012.06.905

Judge, T. A., Scott, B. A., \& Ilies, R. (2006). Hostility, job attitudes, and workplace deviance: Test of a multilevel model. Journal of Applied Psychology, 91(1), 126-138.

Kidder, D. L. (2002). The influence of gender on the performance of organizational citizenship behaviors. Journal of Management, 28(5), 629-648. https://doi.org/10.1016/S01492063(02)00159-9

Köverová, M. (2019). Job satisfaction, compassion satisfaction and compassion fatigue in helping professionals in Slovakia. In Psychológia práce a organizácie 2018: Zborník príspevkov (pp. 231243). Košice: UPJŠ v Košiciach.

Kuehn, K. W., \& Al-Busaidi, Y. (2002). Citizenship behavior in a non-western context: An examination of the role of satisfaction, commitment and job characteristics on self-reported OCB. International Journal of Commerce and Management, 12(2), 107-125. https://doi.org/10.1108/eb047446

Leventhal, G. S. (1976). The distribution of rewards and resources in groups and organizations. Advances in Experimental Social Psychology, 9, 91-131. https://doi.org/10.1016/S00652601(08)60059-3

Lind, E. A., \& Tyler, T. R. (1988). The Social Psychology of Procedural Justice. New York: Plenum Press. 
McNeely, B. L., \& Meglino, B. M. (1994). The role of dispositional and situational antecedents in prosocial organizational behavior: An examination of the intended beneficiaries of prosocial behavior. Journal of Applied Psychology, 79(6), 836-844.

Mohammad, J., Habib, F. Q., \& Zakaria, S. (2010). Organizational citizenship behavior and commitment: Do age and tenure make any difference? $B M Q R, 1(3), 28-49$.

Moorman, R. H. (1991). Relationship between organizational justice and organizational citizenship behavior: Do fairness perception influence employee citizenship? Journal of Applied Psychology, 76, 845-855.

Nandan, T., \& Azim, A. M. M. (2015). Organizational justice and organizational citizenship behavior: Mediating role of psychological capital. American International Journal of Social Science, 4(6), 148-156.

Nielsen, T. M., Hrivnak, G. A., \& Shaw, M. (2009). Organizational citizenship behavior and performance: A meta-analysis of group-level research. Small Group Research, 40(5), 555-577. https://doi.org/10.1177/1046496409339630

Oren, L., Tziner, A., Nahshon, Y., \& Sharoni, G. (2013). Relations between OCBs, organizational justice, work motivation and self-efficacy. Academy of Economic Studies, 15(34), 505-516. https://www.econstor.eu/bitstream/10419/168796/1/aej-v15-i34-p505.pdf

Organ, D. W. (1988). Organizational citizenship behavior: The good soldier syndrome. Lexington: Lexington Books.

Organ, D. W. (1997): Organizational citizenship behavior: It's construct clean-up time. Human Performance, 10(2), 85-97. https://doi.org/10.1207/s15327043hup1002_2

Organ, D. W., \& Lingl, A. (1995). Personality, satisfaction, and organizational citizenship behavior. The Journal of Social Psychology, 135(3), 339-350. https://doi.org/10.1080/00224545.1995.9713963

Organ, D. W., Podsakoff, P. M., Mackenzie, S. B. (2006). Organizational citizenship behavior: Its nature, antecedents, and consequences. USA: Sage Publications.

Podsakoff, P. M., Mackenzie, S. B., Paine, J. B., \& Bachrach, D. G. (2000). Organizational citizenship behaviors: A critical review of the theoretical and empirical literature and suggestions for future research. Journal of Management, 26(3), 513-563. https://doi.org/10.1016/S0149-2063(00)00047-7

Rioux, S. M., \& Penner, L. A. (2001). The causes of organizational citizenship behavior: A motivational analysis. Journal of Applied Psychology, 86(6), 1306-1314. https://doi.org/10.1037/0021-9010.86.6.1306

Rovenská, D. (2017). Vývoj konceptu procedurálnej spravodlivosti a jej súčasné postavenie v sociálnej psychológii. Československá psychologie, 61(2), 169-182.

Schraggeová, M., \& Rošková, E. (2016). Záväzok k organizácii vo vzt’ahu k organizačnému občianskemu správaniu a úmyslu zotrvat' v organizácii. Československá psychologie, 60(1), 38-50.

Smith, C., Organ, D. W., \& Near, J. P. (1983). Organizational citizenship behavior: Its nature and antecedents. Journal of Applied Psychology, 68(4), 653-663.

Sousa, F., H., \& Vala, J. (2002). Relational justice in organizations: The group-value model and support for change. Social Justice Research, 15, 99-121. https://doi.org/10.1023/A:1019967705790

Spector, P. E., \& Fox, S. (2009). Organizational citizenship behavior checklist (OCB-C). http://shell.cas.usf.edu/ pspector/scales/ocbcpage.html/.

Spector, P. E., \& Che, X. X. (2014). Re-examining citizenship: How the control of measurement artifacts affects observed relationships of organizational citizenship behavior and organizational variables. Human Performance, 27(2), 165-182. https://doi.org/10.1080/08959285.2014.882928

Sunshine, J., \& Heuer, L. (2002). Deservingness and perceptions of procedural justice in citizen encounters with the police. In M. Ross, \& D. T. Miller (Eds.), The justice motive in everyday life (pp. 397-416). New York: Cambridge University Press.

Thibaut, J., \& Walker, L. (1975). Procedural justice: A psychological analysis. Hillsdale, NJ: Erlbaum. 
Tyler, T. R. (1989). The psychology of procedural justice: A test of the group value model. Journal of Personality and Social Psychology, 57, 830-838.

Wagner, S. L., \& Rush, M. C. (2000). Altruistic organizational citizenship behavior: Context, disposition, and age. The Journal of Social Psychology 140, 379-391. https://doi.org/10.1080/00224540009600478

Wanxian, L., \& Weiwu, W. (2007). A demographic study on citizenship behavior as in-role orientation. Personality and Individual Differences, 42, 225-234. https://doi.org/10.1016/j.paid.2006.06.014

Williams, L. J., \& Anderson, S. E. (1991). Job satisfaction and organizational commitment as predictors of organizational citizenship and in-role behaviors. Journal of Management, 17, 601617. https://doi.org/10.1177/014920639101700305

Williams, S., Pitre, R., \& Zainuba, M. (2002). Justice and organizational citizenship behavior intentions: Fair rewards versus fair treatment. The Journal of Social Psychology, 142(1), 33-44. https://doi.org/10.1080/00224540209603883

Zeinabadi, H., \& Salehi, K. (2011). Role of procedural justice, trust, job satisfaction, and organizational commitment in organizational citizenship behavior (OCB) of teachers: Proposing a modified social exchange model. Social and Behavioral Sciences, 29, 1472-1481. https://doi.org/10.1016/j.sbspro.2011.11.387

Zhao, H., Peng, Z., \& Chen, H. K. (2014). Compulsory citizenship behavior and organizational citizenship behavior: The role of organizational identification and perceived interactional justice. Journal of Psychology, 152(2), 177-196. https://doi.org/10.1080/00223980.2013.768591

\section{O autorce}

Mgr. Denisa Rovenská, PhD. je absolventkou Filozofickej fakulty Univerzity Pavla Jozefa Šafárika v Košiciach v odbore psychológia. Doktorandské štúdium absolvovala na Filozofickej fakulte Univerzity Pavla Jozefa Šafárika v Košiciach v odbore sociálna psychológia a psychológia práce. V súčasnosti pracuje ako odborná asistentka na Fakulte verejnej správy Univerzity Pavla Jozefa Šafárika v Košiciach. Jej pedagogická ako aj vedecko-výskumná činnost' je zameraná na problematiku sociálnej spravodlivosti.

\section{Kontaktní údaje:}

Adresa: Katedra sociálnych štúdií Fakulty verejnej správy, Univerzita Pavla Jozefa Šafárika v Košiciach, Popradská 66, 04132 Košice

E-mail: denisa.rovenska@upjs.sk

Rovenská, D. (2019). Organizačné občianske správanie, organizačná spravodlivost' a sociodemografické ukazovatele. E-psychologie, 13(3), 42-59. https://doi.org/10.29364/epsy.350 